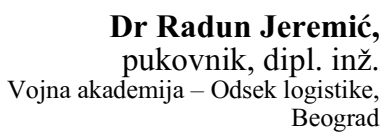

Dr Radun Jeremić,

Beograd

\section{NEKI ASPEKTI PRIMENE RAZLIČITIH
METODA U ISPITIVANJU EKSPLOZIVNIH \\ NEKI ASPEKTI PRIMENE RAZLIČITIH
METODA U ISPITIVANJU EKSPLOZIVNIH MATERIJA}

UDC: $622.1 / .4: 620.181 .4$

Rezime:

Eksplozivne materije, pored relativno velike osetljivosti na dejstvo spoljnih impulsa, imaju sklonost ka termičkoj dekompoziciji usled čega postoji opasnost od njihovog samozapaljenja u slučaju ispunjenja kritičnih uslova. Radi toga uspostavljen je čitav sistem ispitivanja i kontrole, čiji je cilj predviđanje ponašanja eksplozivnih materija u različitim uslovima proizvodnje, čuvanja i manipulacije, kako bi se verovatnoća akcidenata svela na minimum. Radi toga se $i$ kod nas primenjuje veliki broj metoda zasnovanih na različitim principima. $U$ radu su analizirane prednosti i nedostaci pojedinih metoda, $i$ dat je kritički osvrt na pouzdanost eksperimentalnih rezultata koji se dobijaju pomoću njih.

Ključne reči: eksplozivne materije, stabilnost, metode ispitivanja, termička dekompozicija, samozapaljenje.

\title{
SOME ASPECTS OF APPLYING DIFFERENT METHODS IN TESTING EXPLOSIVES
}

\section{Summary:}

Apart from relatively high sensitivity to external influences, explosives have sensitivity to thermal decomposition which can cause their autoignition if critical conditions are fulfiled. This was the reason for establishing a whole system of testing and control in order to predict behaviour of explosives under different conditions of production storage and handling and reduce possibilities of accidents to the minimum. For these purposes a number of methods based on various principles are applied in our country as well. The paper analyzes advantages and disadvantages of parthicular methods and gives a critical report on the reliability of experimental results obtained by them.

Key words: explosives, stability, testing methods, thermal decomposition, autoignition.

\section{Uvod}

Eksplozivne materije (EM) spadaju u opasne materije, na osnovu čega su, prema klasifikaciji Organizacije UN, svrstane u prvu grupu opasnosti [1]. Potencijalna opasnost od ovih materija posledica je, pre svega, njihove osetljivosti na spoljne impulse i manje ili više izražene nestabilnosti. Pored ovih kategorija, pri proizvod- nji i manipulaciji mora se uzeti u obzir i toksičnost eksplozivnih materija.

Pri skladištenju i manipulaciji sa eksplozivnim materijama opasnosti se moraju sagledati sa aspekta osetljivosti, stabilnosti i toksičnosti.

$\mathrm{Ne}$ postoje apsolutni pokazatelji osetljivosti eksplozivnih materija na osnovu kojih se pouzdano može proceniti minimalan impuls potreban za inicijaciju. 
To je posledica složenosti fenomena inicijacije. Osetljivost ne zavisi samo od hemijske strukture eksplozivnih materija nego i od velikog broja faktora fizičke prirode, od kojih se neki odnose na fizičko stanje eksplozivnih materija, a drugi na uslove u kojima se odvija proces inicijacije. Zbog toga podaci o osetljivosti eksplozivnih materija predstavljaju samo statističke parametre na osnovu kojih se može utvrditi kolika je verovatnoća da u određenim uslovima može doći do inicijacije. Ako se spoljni uslovi ili fizičko stanje eksplozivnih materija promene, za istu jačinu impulsa verovatnoća inicijacije može se višestruko izmeniti.

Količina energije neophodna za iniciranje procesa eksplozivnog razlaganja za istu eksplozivnu materiju menja se u širokim granicama, što, pre svega, zavisi od oblika početnog impulsa i načina prenosa energije na eksplozivnu materiju. Za inicijaciju eksplozivnog razlaganja nije presudna količina energije, već koncentracija energije u vremenu i prostoru, jer se na taj način mnogo brže dostiže energetska barijera za otpočinjanje procesa razlaganja na nivou molekula eksplozivne materije.

Među različitim oblicima početnih impulsa ne postoji stroga ekvivalentnost $\mathrm{u}$ rezultatima njihovog dejstva na istu eksplozivnu materiju. Na primer, olovoazid je osetljiviji na mehaničko dejstvo, dok je olovostifnat osetljiviji na toplotno dejstvo.

Mnoge eksplozivne materije (baruti, raketna goriva, pirotehničke smeše, privredni eksplozivi) po svojoj prirodi su nestabilna jedinjenja, tako da pod uticajem različitih spoljnih faktora, kao što su temperatura, vlaga, svetlost i dr., vreme- nom menjaju svoje početne karakteristike. Za proces promene početnih karakteristika uobičajen je pojam starenje eksplozivnih materija. Zato vek trajanja eksplozivnih komponenti najčešće i diktira rok upotrebe ubojnih sredstava.

Stabilnost se razmatra, uglavnom, sa aspekta sigurnosti (mogućnosti čuvanja bez opasnosti od spontanog samozapaljenja u skladištima ili neželjenog i opasnog funkcionisanja pri upotrebi) i sa aspekta pouzdanosti.

Pouzdanost eksplozivnih materija može se definisati verovatnoćom funkcionisanja u granicama projektovanih performansi i nakon određenog perioda skladištenja. Aspekt sigurnosti se više odnosi na hemijsku stabilnost, a pouzdanosti na fizičku (mehaničku) i balističku stabilnost, koje većim delom zavise i od hemijske stabilnosti.

Pod stabilnošću eksplozivnih materija podrazumeva se njihova sposobnost da u određenom vremenu u uslovima skladištenja sačuvaju svoje početne fizičke, hemijske i eksplozivne, odnosno balističke karakteristike u granicama koje ce osigurati pouzdano funkcionisanje i bezbednu upotrebu ubojnih sredstava u kojima su laborisane. U tom smislu razlikuju se hemijska, fizička (mehanička) i balistička stabilnost, mada su sve one međusobno zavisne.

Za razliku od osetljivosti i stabilnosti, toksičnost eksplozivnih materija je karakteristika hemijskog sastava koja ne zavisi od spoljnih faktora, pa se na osnovu toga može i precizno definisati.

$\mathrm{Za}$ ispitivanje osetljivosti i stabilnosti eksplozivnih materija primenjuje se veliki broj metoda zasnovanih na različitim principima. Svaka od njih ima svoje pred- 
nosti i nedostatke koji se moraju uzimati u obzir pri analizi i tumačenju rezultata.

\section{Ispitivanje osetljivosti eksplozivnih materija}

Proces eksplozivnog razlaganja eksplozivnih materija može se inicirati različitim spoljnim impulsima (toplotni, mehanički, udarni talas, itd.), tako da se osetljivost mora ispitivati posebno za svaki od njih. Sa aspekta procene mogućnosti samozapaljenja u uslovima skladištenja svakako je najvažnije poznavanje osetljivosti EM na toplotni impuls.

\section{Ispitivanje osetljivosti EM na toplotni početni impuls}

Toplotni impuls može delovati na eksplozivne materije u obliku homogenog i lokalnog zagrevanja.

Homogeno (lagano) zagrevanje odvija se po čitavoj masi eksplozivne materije, izvorom toplote bez plamena, do neke kritične temperature (temperature samopaljenja). Dalji razvoj procesa eksplozivnog razlaganja odvija se po zakonitosti toplotne eksplozije, po kojoj dolazi do samozapaljenja usled narušene ravnoteže između oslobađanja toplote i njene razmene sa okolinom. Inicirani proces sagorevanja dalje može preći u detonaciju, zavisno od vrste eksplozivne materije i uslova u kojima je izvršeno iniciranje. Kod inicijalnih eksplozivnih materija proces, po pravilu, prelazi u detonaciju.

Lokalno zagrevanje (plamen, varnica, usijana žica) primenjuje se za pripalu baruta i raketnih goriva pri opaljenju projektila, kao i za pobuđivanje detonacije u detonatorima. U tom slučaju uspostavlja se značajan gradijent temperature, pri čemu je karakteristična pojava lokalne zone razlaganja koja se kroz eksplozivnu materiju širi samorasprostirujućim mehanizmom.

Kao mera osetljivosti eksplozivnih materija na toplotni impuls, obično, služi temperatura paljenja, odnosno vreme zadrške (period indukcije).

Rezultati ispitivanja osetljivosti eksplozivnih materija mogu varirati u širokim granicama, zavisno od uticaja različitih parametara, kao što su masa ispitivanog uzorka, granulacija, veličina kristala, prisustvo primesa, itd.

$\mathrm{Na}$ slikama 1 do 5 dati su neki rezultati ispitivanja EM na toplotni impuls koji potvrđuju navedenu činjenicu [2].

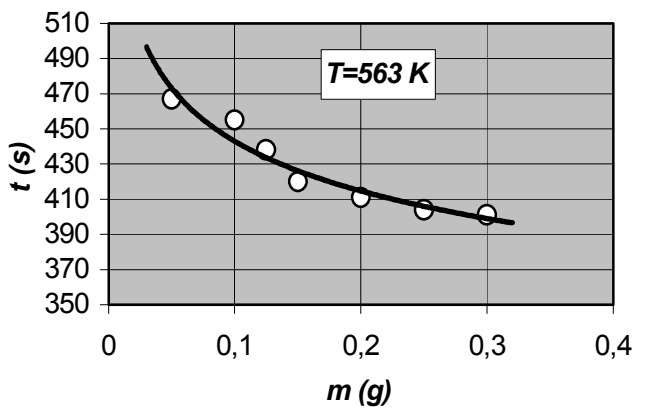

Sl. 1 - Uticaj mase uzorka na vreme zadrške za TNT

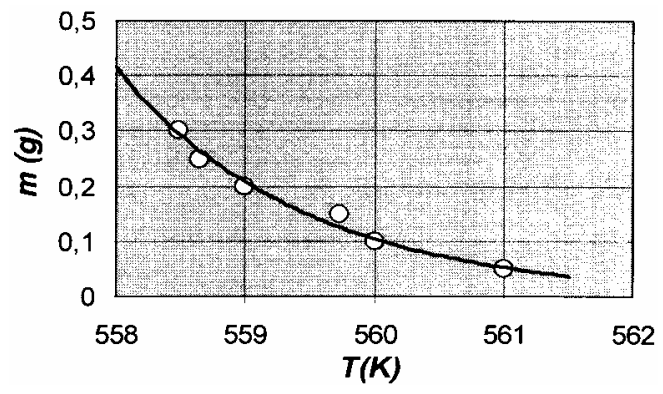

Sl. 2 - Uticaj mase uzorka na temperaturu paljenja TNT-a 


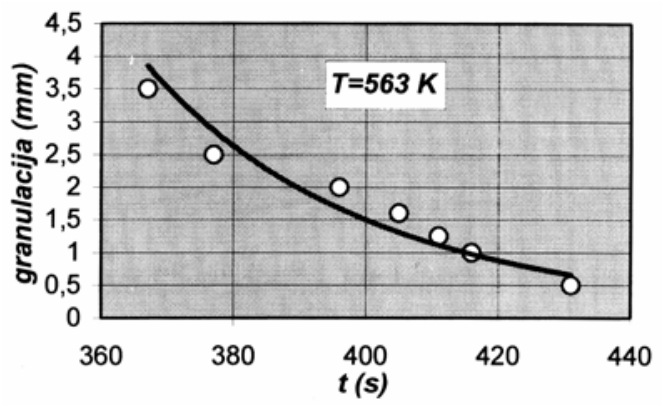

Sl. 3 - Rezultati merenja uticaja granulacije uzorka TNT na vreme zadrške

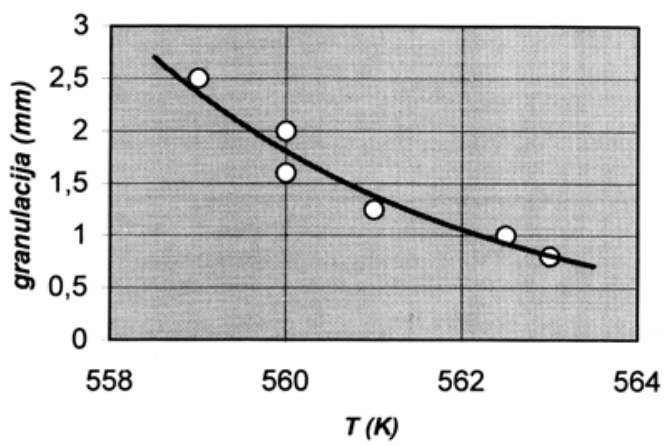

Sl. 4 - Uticaj mase uzorka na vreme zadrške za TNT

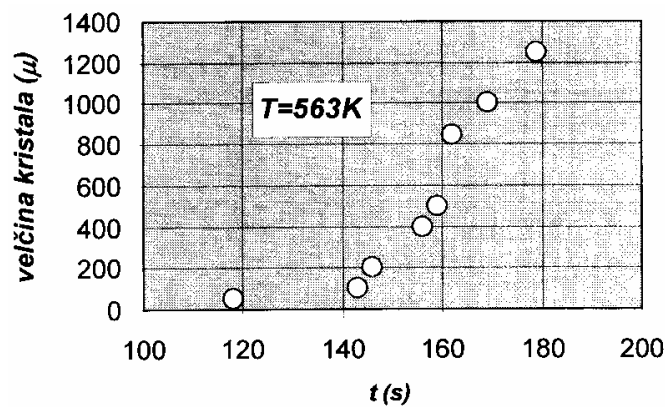

Sl. - 5-Uticaj veličine kristala na vreme zadrške kod oktogena

Osnovni nedostatak ove metode je što ne uzima u obzir uticaj mase i gasovitih produkata na mehanizam procesa termičke dekompozicije EM (ispituje se mala količina uzorka u otvorenoj epruveti). Dobijeni rezultati su relativni i ne mogu se koristiti za predviđanje ponašanja EM u realnim uslovima.

U istu svrhu primenjuje se tzv. ,cookoff" metoda [3]. Uzorak se ispituje u zatvorenoj čeličnoj posudi (slika 6), a prati se promena temperature i pritiska $\mathrm{u}$ posudi pri programiranom zagrevanju ili $\mathrm{u}$ izotermnim uslovima, sve do paljenja, odnosno eksplozije. Ni ova metoda ne uzima u obzir uticaj mase na mehanizam procesa termičke dekompozicije, što je njen osnovni nedostatak.

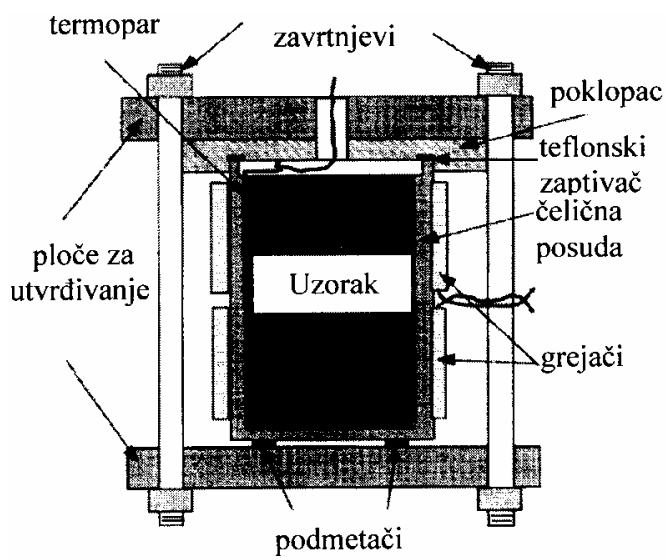

Sl. 6 - Šematski prikaz ,cookoff“ metode

\section{Termohemijska ispitivanja eksplozivnih materija}

U poslednjih dvadesetak godina za termohemijska ispitivanja eksplozivnih materija masovno se primenjuju različite termičke metode kojima se prate fizičke i hemijske promene $\mathrm{u}$ ispitivanom uzorku $\mathrm{u}$ funkciji temperature ili vremena. Pomoću njih se ispituje kinetika procesa dekompozicije, kompatibilnost pojedinih komponenti koje ulaze u sastav eksplozivne materije, određuje se entalpija dekompozicije i faznih prelaza, toplotni ka- 
pacitet, karakteristične temperature, termička stabilnost, itd.

\section{Diferencijalna termalna analiza (DTA)}

Princip DTA zasniva se na merenju temperaturne razlike između referentnog i ispitivanog uzorka, koja nastaje kao posledica oslobađanja ili apsorpcije toplote $\mathrm{u}$ ispitivanom uzorku, pri programiranom zagrevanju (slika 7).

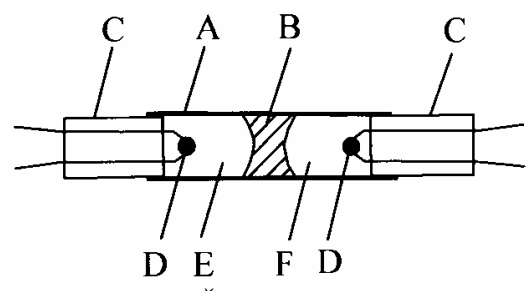

Sl. 7 - ̌̌ema DTA ćelije:

$A$ - cevčica od nerđajućeg čelika, B-keramički umetak, $C$-izolator termopara, D-termoparovi, prostor za uzorak, prostor za referentni uzorak $30 \mathrm{mg}$.

Masa uzorka je u granicama od 3 do

Kvalitativni podaci koji se dobijaju pomoću DTA vrlo su korisni, dok su kvantitativni rezultati nepouzdani jer termička osetljivost DTA sistema nije konstantna, a količina ispitivanog uzorka je vrlo mala. Zato se i ne mogu sa većom pouzdanošću upoređivati kvantitativni podaci različitih materijala.

Prvo uočavanje pojave oslobađanja toplote usled neke reakcije u uzorku (egzoterm) često se primenjuje kao kriterijum termičke stabilnosti. Različiti uzorci iste EM mogu se upoređivati samo ako se ispitivanje realizuje pod identičnim uslovima. Međutim, na osnovu DTA ne može se utvrditi pouzdana skala za upoređivanje relativne stabilnosti različitih EM, jer se razlikuju i njihovi mehanizmi dekompozicije. Samo kod malog broja EM dekompozicija se odvija po jednostavnim kinetičkim zakonima, kao što je npr. zakon prvog reda (slika 8). Kada se takve materije zagrevaju na nekoj temperaturi, njihova brzina dekompozicije je maksimalna na samom početku. Brzina pada eksponencijalno sa vremenom kako se smanjuje količina uzorka.

Red reakcije određen je eksponentom padajuće funkcije u jednačini brzine reakcije.

Dekompozicija većine EM odvija se prema zakonima autokatalitičkih reakcija (slika 9). Na bilo kojoj temperaturi po-

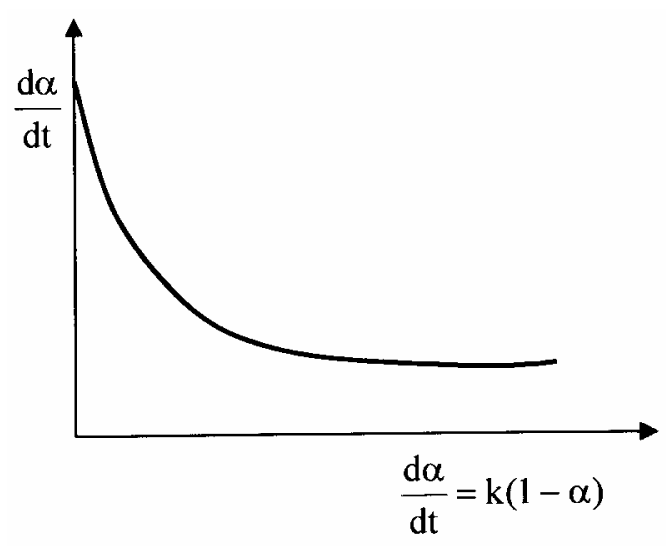

Sl. 8 - Dekompozicija prema zakonu prvog reda

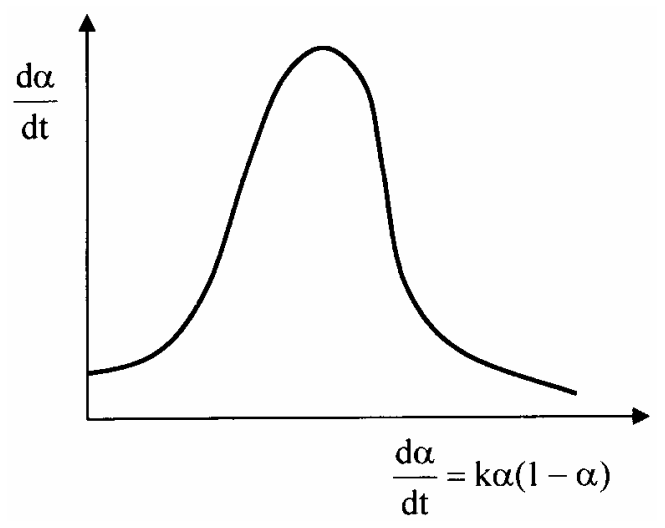

Sl. 9 - Autokatalitička dekompozicija 
stoji određeno vreme kašnjenja pre nego što dođe do maksimalne brzine dekompozicije. Zato mnogi materijali, čija se dekompozicija odvija izrazito autokatalitički, izgledaju stabilniji nego što jesu.

$\mathrm{Na}$ osnovu ovakvih ispitivanja često se izvode pogrešni zaključci da se sa EM može bezbedno manipulisati na bilo kojoj temperaturi ispod prve pojave egzoterma. Ovakvo tumačenje je pogrešno i opasno, jer maksimalna bezbedna temperatura za manipulaciju sa EM zavisi od njihove mase, oblika i uslova kojima je EM prethodno bila izložena.

Normalna DTA ćelija je izolovana, zbog čega se ispitivanje odvija $u$ atmosferi koju generiše sam uzorak. U takvim uslovima može doći do značajnih nehomogenosti i sekundarnih reakcija što omogućuje da se identifikuju najznačajniji problemi kompatibilnosti EM. Međutim, za EM je vrlo bitno da se ispitivanja, pored ovih uslova, sprovedu i u uslovima kontinuiranog odvođenja produkata dekompozicije, na osnovu čega se mogu identifikovati sigurnosni problemi koji proističu iz uslova čuvanja. Proces starenja EM različito se odvija u zatvorenom i otvorenom prostoru.

Postoji više metoda za određivanje kinetičkih konstanti na osnovu DTA analiza [4]. Međutim, te metode daju pogrešne rezultate kada se dekompozicija odvija autokatalitički, kao što je to slučaj kod većine EM. Zato je vrlo opasno razvijati model za predviđanje ponašanja EM baziran na kinetičkim konstantama dobijenim pomoću DTA (ili bilo koje druge metode koja se zasniva na programiranom zagrevanju uzorka).

U jednu od najznačajnijih primena DTA spada ispitivanje hemijske kompa- tibilnosti. Radi toga se pod identičnim uslovima vrši ispitivanje čistog eksploziva i određene smeše. Na osnovu razlike u dobijenim termogramima zaključuje se o međusobnom uticaju komponenti, odnosno o hemijskoj kompatibilnosti.

$\mathrm{Na}$ slici 10 prikazan je problem nekompatibilnosti HMX i olova. Kriva 1 prikazuje termičku dekompoziciju HMX, čija je glavna primesa RDX, kako to prikazuje dupli endoterm nešto ispod $200^{\circ} \mathrm{C}$. Kriva 2 prikazuje isti HMX sa dodatkom olovnog praha. Endoterm sada postaje egzoterm, a uzorak eksplodira na $50^{\circ} \mathrm{C}$ u odnosu na sam HMX.

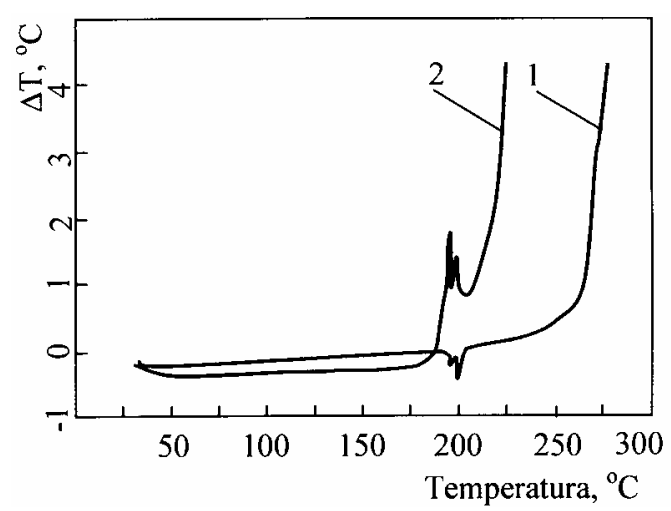

Sl. 10 - Uticaj olova na termičku stabilnost HMX: 1 - termogram HMX; 2 - termogram HMX sa dodatkom praha olova

Ova smeša nije bezbedna, a kod sličnih sistema dolazi do samopaljenja u tehnološkim operacijama presovanja $u$ velikim presama.

Da bi se problem hemijske kompatibilnosti potpunije ispitao, neophodno je primeniti i druge metode.

\section{Diferencijalna skenirajuća kalorimetrija (DSC)}

Po izgledu i načinu rada DSC je vrlo sličan DTA. Međutim, za razliku od 
DTA, princip DSC se zasniva na merenju razlike u toplotnim fluksevima između referentnog i ispitivanog uzorka (slika 11).

Ako se ispitivani i referentni uzorak greju konstantnom brzinom u kontrolisanoj atmosferi, povećanje temperature $\mathrm{u}$ oba uzorka biće podjednako, osim ako u ispitivanom uzorku ne dođe do nekih promena prouzrokovanih zagrevanjem. U tom slučaju temperatura uzorka može biti viša ili niža od temperature referentnog uzorka, zavisno od karaktera procesa koji se odvija (egzoterman ili endoterman). Temperaturna razlika direktno je proporcionalna razlici toka toplote. Razlika u toplotnim tokovima registruje se pomoću „chromel“ termopara, a temperatura uzorka registruje se pomoću „chromel-alumel“" termopara. Dobijena toplotna promena, koja predstavlja energiju faznog prelaza ili reakcije, registruje se u obliku odgovarajuće krive (slika 12). Iznos energetske promene je proporcionalan površini ispod krive.

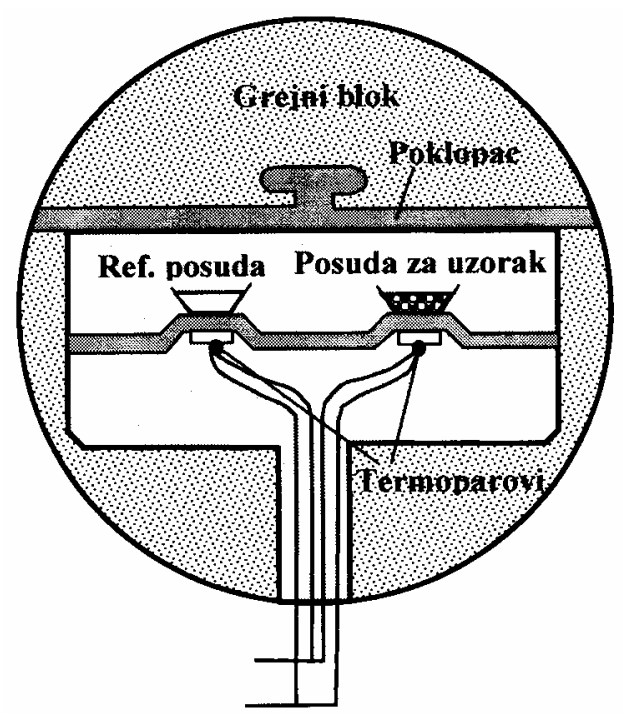

Sl. 11 - Šema DSC ćelije

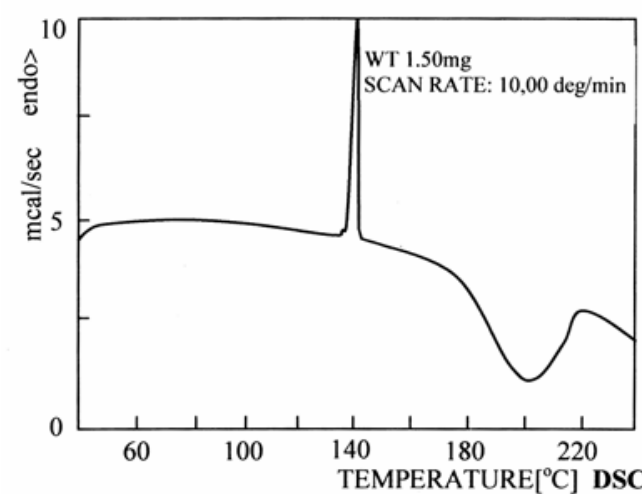

Sl. 12 - DSC termogram pentrita [5]

Pomoću DSC moguće je odrediti promenu entalpije, kinetičke parametre, specifičnu toplotu, temperature faznih promena, kao i utvrđivanje hemijske kompatibilnosti pojedinih komponenti $\mathrm{u}$ uzorku.

Do sada je publikovan veliki broj metoda za određivanje kinetičkih parametara pomoću DSC [6]. Sve te metode zasnivaju se na programiranom zagrevanju uzorka. Međutim, ni jedna od njih ne može dati dovoljno pouzdane kinetičke parametre za kompleksne reakcije kakva je termička dekompozicija eksplozivnih materija. Zbog toga je neophodno izvoditi ispitivanja pri konstantnoj temperaturi tako da se brzina toplotnih promena prati $\mathrm{u}$ funkciji vremena [7].

Na slici 13 prikazane su izotermičke DSC krive za nekoliko vrsta eksplozivnih materija.

Može se primetiti da se brzine termičke dekompozicije veoma razlikuju za različite materije, što znači da bi predviđanje ponašanja EM na osnovu jednostavnih kinetičkih zakona bilo pogrešno i opasno.

Brzina reakcije i količina reaktanata fundamentalni su podaci neophodni za 


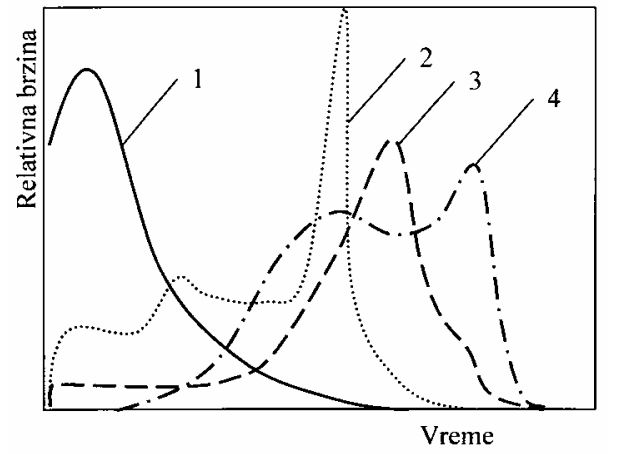

Sl. 13 - Izotermalne DSC krive:

$1-R D X / T N T$ (65/35), 2 - kompozitno raketno gorivo, $3-H M X, 4-T A T B$

bilo kakvu kinetičku studiju. Ove vrednosti pouzdano se mogu dobiti samo na osnovu ispitivanja u izotermalnim uslovima. Bez obzira na to, zbog vrlo male količine ispitivanog uzorka (najviše nekoliko mg) ne može se uočiti uticaj mase na proces termičke dekompozicije EM. To je i osnovni razlog što ni DSC ne može dati pouzdane kvantitativne podatke za predviđanje ponašanja EM.

\section{Termogravimetrijska analiza (TGA)}

Princip TGA zasniva se na praćenju promene mase uzorka pri njegovom programiranom zagrevanju. Pošto je nemoguće da termopar bude u uzorku i da se istovremeno prati promena mase, učinjen je kompromis u preciznosti merenja promene mase i promene temperature. $\mathrm{Na}$ taj način termopar meri samo temperaturu oko uzorka, a ne i u samom uzorku, gde se temperatura, zbog autokatalitičkih reakcija i samozagrevanja, može znatno razlikovati. Pored toga, isparljivi i gasoviti produkti dekompozicije kontinuirano napuštaju uzorak bez značajnijeg uticaja na sam mehanizam procesa, što ne odgovara realnim uslovima.
Kao i kod ostalih termičkih metoda i kod TGA se radi sa malim količinama uzorka, tako da se ne može uočiti uticaj mase na proces dekompozicije.

Kod EM brza dekompozicija na određenoj temperaturi proizvodi određen potisak na posudu za uzorak, što dovodi i do grešaka u merenju mase. Uz to, pri burnoj dekompoziciji (eksploziji) uzorka može doći do oštećenja osetljivih i skupih delova, što uslovljava da se radi sa vrlo malim količinama uzorka.

Može se konstatovati da je zajednički nedostatak DTA, DSC i TGA u ispitivanju EM vrlo mala količina ispitivanog uzorka, čime se isključuje uticaj mase na proces dekompozicije, kao i mala pouzdanost kvantitativnih rezultata. Zato su one više namenjene za relativna ispitivanja, ispitivanja kompatibilnosti i uticaj primesa i sastava na termohemijske osobine EM.

\section{„Accelerating Rate" kalorimetar (ARC)}

Uređaj ARC konstruisan je za ispitivanje procesa koje prati oslobađanje toplote usled hemijskih reakcija [7]. Kao takav pogodan je za studiju dekompozicije eksplozivnih materija. Princip rada uređaja zasniva se na praćenju promene temperature i pritiska izdvojenih gasova, pri adijabatskim i izotermnim uslovima, koji nastaju usled egzotermnih reakcija pri dekompoziciji uzorka EM. Uređaj vrši i automatski proračun kinetičkih konstanti.

Što se tiče EM može se reći da ARC daje sumnjive rezultate. Problem proističe iz fundamentalne jednačine adijabat- 
ske kalorimetrije na kojoj se i zasniva princip rada uređaja:

$C_{p} \frac{d T}{d t}=Q f(\alpha) Z e^{-E / R T}$

gde je:

$C_{p}$ - toplotni kapacitet,

$T$ - temperatura,

$t$ - vreme,

$Q$ - toplota reakcije,

$\alpha$ - udeo izreagovanog reaktanta u ne-

kom vremenu,

$Z$ - predeksponencijalni faktor,

$E$ - energija aktivacije,

$R$ - gasna konstanta.

Jednačina (1) precizno opisuje temperaturno-vremenski tok dekompozicije samo ako su uslovi zaista adijabatski. U tom slučaju $C_{p}$ će biti konstantan u određenom temperaturnom intervalu, stanje uzorka u bilo kom vremenu odražavaće samo jedna temperatura, a mehanizam se neće menjati sa promenom količine uzorka. Međutim, nijedan od ovih uslova nije $\mathrm{u}$ potpunosti ispunjen kada se ispituje čvrsti uzorak relativno velike mase, koji oslobađa znatnu količinu toplote. Eksplozivne materije oslobađaju toplotu pri dekompoziciji, imaju slabu toplotnu provodljivost, usled čega dolazi do samozagrevanja uzorka koje je najizraženije u samom centru.

Prema tome, jedna temperatura ne može opisati sistem. Ova činjenica prouzrokuje glavnu grešku kad su u pitanju EM. Dekompozicija EM je kompleksan proces čiji se mehanizam menja sa temperaturom, pritiskom i smanjenjem početne mase uzorka. To znači da $Q$ i $f(\alpha)$ nisu konstante, što dovodi do dodatne greške.
Može se zaključiti da ne postoji procedura za dobijanje pouzdanih kinetičkih konstanti kompeksnih reakcija dekompozicije EM pomoću ARC.

\section{Koncept kritične temperature odnosno kritičnog prečnika}

Sa aspekta sigurnosti najvažniji kriterijum je kritična temperatura $\left(T_{\partial}\right)$, koja se definiše kao najniža temperatura pri kojoj kod određenog materijala može doći do samozapaljenja usled samozagrevanja. Kritična temperatura odnosi se na materijal tačno određenih fizičko-hemijskih karakteristika, oblika i dimenzija. Analogno, može da se definiše i kritični prečnik $\left(D_{\partial}\right)$ kao najmanji prečnik uzorka nekog materijala kod kojeg na određenoj temperaturi može doći do samozapaljenja.

Kod čvrstih materija, kod kojih se proces prenosa toplote odvija kondukcijom, vrednost kritičnih parametara može se odrediti na osnovu teorije toplotne eksplozije Frank-Kameneckog [8], prema kojoj se kriterijum samozapaljenja može predstaviti u obliku bezdimenzionalnog parametra $(\delta)$ i njegove kritične vrednosti:

$\delta=\frac{\Delta H_{r} \rho}{4 \lambda} \frac{E}{R T_{0}^{2}} D^{2} A e^{-\frac{E}{R T_{0}}}$

gde je:

$D$ - karakteristična dimenzija uzorka, odnosno prečnik posude u kojoj se uzorak nalazi,

$T_{0}$ - temperatura okoline,

$A$ - predeksponencijalni faktor u Arenijusovoj jednačini,

$\lambda$ - koeficijent toplotne provodljivosti, $\rho$ - gustina uzorka, 
$\Delta H_{r}$ - toplota reakcije,

$E$ - energija aktivacije,

$R$ - univerzalna gasna konstanta.

Parametar $\delta$ objedinjuje osnovne osobine sistema: brzinu i toplotu reakcije, toplotnu provodljivost i dimenzije uzorka.

Kritični uslovi nastaju kada je $\delta=\delta_{k r}$, jer u tom slučaju više nije mogućna stacionarna raspodela temperature, pa dolazi do samozapaljenja. Kritična vrednost $\delta$ zavisi od geometrijskog oblika posude (uzorka) i iznosi: za kuglu 3,32, za cilindar 2,00, za pločicu 0,88 .

Jednačina (2) omogućuje da se odredi kritični prečnik uzorka (ili kritična temperatura) kod koje dolazi do samozapaljenja:

$D_{k r}=\sqrt{\frac{4 \lambda \delta R T_{0}^{2} e^{\frac{E}{R T_{o}}}}{\Delta H_{r} \rho E A}}$

Izraz (3) predstavlja osnovu za praćenje hemijske stabilnosti baruta i raketnih goriva laborisanih u klasičnoj i raketnoj municiji, sa aspekta mogućnosti samozapaljenja po metodi mikrokalorimetrije.

Na slici 14 prikazani su eksperimentalni rezultati merenja zavisnosti kritične temperature od prečnika uzorka za nekoliko brizantnih eksploziva [9].

Eksperimentalni rezultati očigledno pokazuju koliko kritična temperatura zavisi od veličine uzorka.

\section{Ispitivanje hemijske stabilnosti}

Eksplozivne materije su, zbog svoje relativne nestabilnosti, sklone laganoj termičkoj dekompoziciji. Ova pojava je

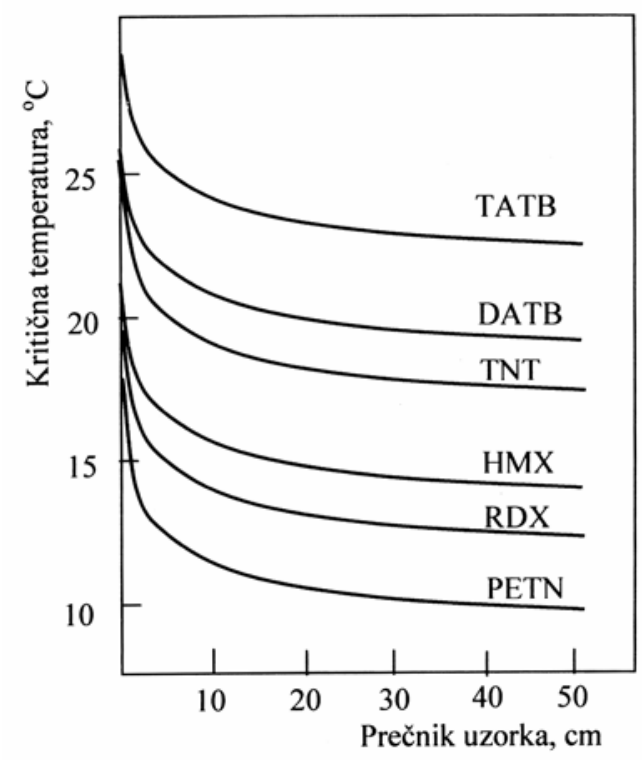

Sl. 14 - Zavisnost kritične temperature od prečnika uzorka za nekoliko vrsta eksploziva

posebno izražena kod pogonskih eksplozivnih materija (baruti i raketna goriva) koje u svom sastavu sadrže nitrocelulozu. Dekompozicija nitroceluloze je egzoterman autokatalitički proces, koji ima za posledicu samozagrevanje pogonskog punjenja, usled čega, u određenim kritičnim uslovima, može doći čak i do njenog samozapaljenja sa katastrofalnim posledicama, što potvrđuju i akcidenti koji su se događali, kako u svetu, tako i kod nas.

Logično, ovoj problematici odavno se posvećuje velika pažnja. Objavljen je veliki broj radova kao rezultat težnje istraživača da reše problem hemijske stabilnosti, i uveden veliki broj metoda za ispitivanje stabilnosti.

Metodologija i metode ispitivanja hemijske stabilnosti kod nas su propisane standardom SNO 8069/91 [10].

Metoda grejanja na $100^{\circ} \mathrm{C}$ sprovodi se na taj način što se uzorak greje na $100^{\circ} \mathrm{C} \mathrm{u}$ 
standardizovanim uslovima. Mera hemijske stabilnosti je vreme do pojave smeđih gasova azotnih oksida.

Metilvioletna metoda $\mathrm{na} 120^{\circ} \mathrm{C}$ ili $134,5^{\circ} \mathrm{C}$ zasniva se na merenju vremena do potpune promene boje metilvioletne hartije, usled razlaganja uzorka baruta ili RG na povišenoj temperaturi.

Bergman-Junkova metoda na $120^{\circ} \mathrm{C}$ ili $132^{\circ} \mathrm{C}$ sprovodi se tako da se uzorak greje određeno vreme u standardizovanim uslovima, a oslobođeni azotni oksidi se apsorbuju u odgovarajućem rastvoru. Kriterijum stabilnosti je količina azotnih oksida apsorbovanih u rastvoru koji se određuju kvantitativno.

Osnovni nedostaci ove tri metode su u tome što ne uzimaju u obzir uticaj mase uzorka na brzinu procesa dekompozicije, zatim visoka temperatura ispitivanja i nepostojanje korelacije između potenci- jalnog uzroka samozapaljenja (oslobođena toplota) i merenog parametra.

Metoda praćenja sadržaja stabilizatora zasniva se na periodičnom određivanju sadržaja aktivnog stabilizatora $u$ barutima i raketnim gorivima u toku skladištenja, a kao kriterijum stabilnosti definisana je granica ispod koje količina aktivnog stabilizatora ne sme pasti.

Nedostatak ove metode jeste što ne postoji pouzdana relacija između količine stabilizatora i mogućnosti samozapaljenja, jer se ne uzima u obzir uticaj mase.

Metoda mikrokalorimetrije originalna je domaća metoda koja se zasniva na teoriji toplotne eksplozije. Princip se sastoji u određivanju kritičnog prečnika uzorka kod kojeg može doći do samozapaljenja. Metoda povezuje direktni uzrok samozapaljenja, količinu oslobođene toplote sa veličinom uzorka (uticaj mase)

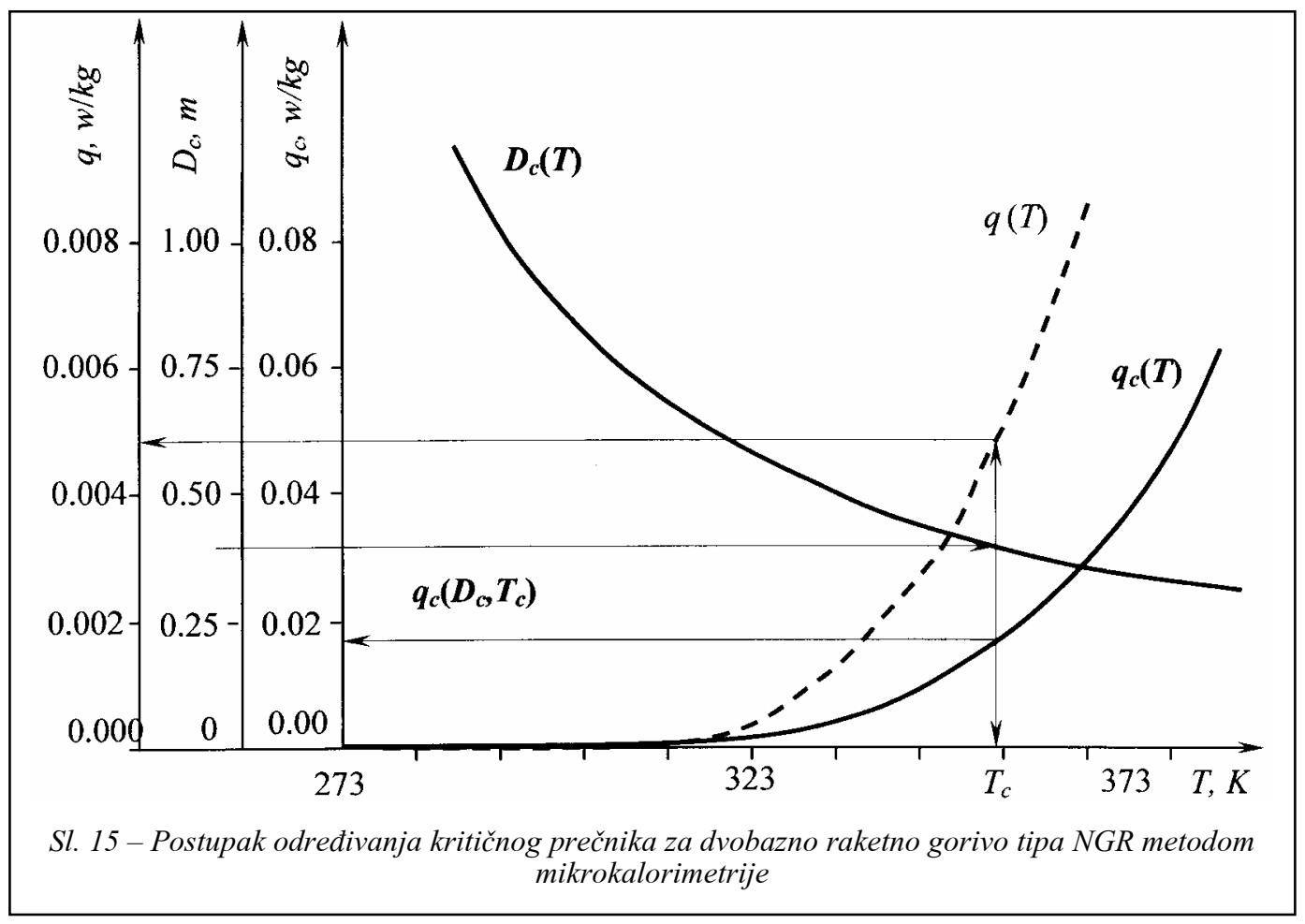


što je njena glavna prednost u odnosu na ostale metode.

Na slici 15 prikazani su rezultati merenja kritičnog prečnika i temperature za jedan tip dvobaznog raketnog goriva [11].

Osnovni nedostatak ove metode je nepouzdano merenje temperaturne razlike $\mathrm{u}$ centru ispitivanog uzorka, jer su promene vrlo male i umnogome zavise od pripreme uzorka, kao i drugih uticajnih faktora.

Pored ovih glavnih metoda postoji još nekoliko pomoćnih metoda za ispitivanje hemijske stabilnosti (metoda grejanja pod vakuumom, Holand-test, Hanzenova metoda, $\mathrm{i}$ dr.).

Treba naglasiti da se konačna ocena hemijske stabilnosti nekog uzorka može doneti samo na osnovu rezultata ispitivanja svih metoda i, po potrebi, pomoćnih. Pri tome, treba uzeti u obzir i uslove čuvanja realnih pogonskih punjenja, njihovu veličinu, način laboracije, itd., što podrazumeva i veliko iskustvo u ovoj oblasti.

\section{Zaključak}

Osetljivost i stabilnost eksplozivnih materija, pored hemijske strukture, $u$ velikoj meri zavise i od velikog broja faktora fizičke prirode, pre svega mase i uslova okoline, zatim gustine, veličine i oblika čestica i kristala, itd. Predviđanje ponašanja EM u različitim uslovima čuvanja i eksploatacije izuzetno je složeno. Radi toga se u praksi primenjuje veliki broj metoda koje se zasnivaju na različitim principima. Svaka od njih ima prednosti i nedostatke koji se uvek moraju imati u vidu pri tumačenju rezultata. Da bi se dobila realna slika osetljivosti i stabilnosti EM neophodno je da se svaki konkretan sastav eksplozivne materije ispita pomoću različitih metoda. Sa aspekta mogućnosti samozapaljenja dominantan uticaj ispoljava efekat mase, odnosno veličina eksplozivnog punjenja koji se može uzeti u obzir jedino preko kriterijuma kritičnog prečnika ili kritične temperature. Metoda mikrokalorimetrije, koja je razvijena kod nas, zasniva se na ovom kriterijumu, zbog čega ima prednost u odnosu na ostale metode.

\section{Literatura:}

[1] DOD 6055.9-STD: DOD Ammunition and Explosives Safety Standards, Ministarstvo odbrane SAD, 1999.

[2] Jeremić, R.: Istraživanje uticaja nekih parametara na osetljivost eksplozivnih materija na toplotni impuls, VTG, br. 3, 2002

[3] Ho, S. Y., Thermomechanical Properties of Rocket Propellants and Correlation with Cookoff Behaviour, Propellants, Explosives, Pyrotechnics, Vol. 20, 1995.

[4] Mackenzie, R. C.: Differential Thermal Analysis, Academic Press, London-New York, 1970

[5] Stanković, M. i dr.: Ispitivanje starenih elastičnih eksploziva na bazi pentrita i poliuretanskog veziva pomoću DSC i IR, 21. simpozijum JKEM, Tara, 2001.

[6] Stanković, M.: Termijska dekompozicija i sagorevanje nitrogvanidina i nitrogvanidinskih baruta, Doktorska disertacija, TMF, Beograd, 1998.

[7] Rogers, R. N.; Rogers, J. L.: Explosives Science, Los Alamos, http://home.att.net/ rnrogers.

[8] Merzhanov, G. A.; Abramov, B. A.: Thermal Explosion of Explosives and Propellants, Propellants, Explosives, Pyrotechnics, 6, 1981

[9] Dobratz, B. M.: LLNL Explosives Handbook, Properties of Chemical Explosives and Explosives Simulants, Lawrece Livermore National Laboratory, 1981.

[10] SNO 8069/91: Praćenje hemijske stabilnosti baruta i raketnih goriva, 1991.

[11] Čolaković, M.: Probability Estimation for the Self-Ignition of the Gun powder, Propellants, Explosives, Pyrotechnics, 17, 1992. 